\title{
APPLICATION OF THE ANALYTIC HIERARCHY PROCESS IN DETERMINING RELATIVE IMPORTANCE OF RELATIONSHIP MARKETING VARIABLES FOR COMPANIES IN THE NIGERIAN FOOD AND BEVERAGE INDUSTRY
}

\author{
Bolajoko N. Dixon-Ogbechi* \\ Faculty of Business Administration \\ University of Lagos \\ Akoka - Yaba, Lagos, Nigeria \\ E-mail: dixonogbechi@yahoo.com \\ Elizabeth M. Haran \\ Bertolon School of Business \\ Salem State College \\ Salem, MA, USA \\ E-mail: eharan@salemstate.edu \\ Joseph F. Aiyeku \\ Bertolon School of Business \\ Salem State College \\ Salem, MA, USA \\ E-mail: jaiyeku@,salemstate.edu
}

\begin{abstract}
Marketing practices and strategies are situation specific and are a function of many variables. Hence, organizations will need to design different marketing strategies and policies to achieve their set marketing goals and objectives. Relationship marketing is one such contemporary marketing strategy employed in both developed and developing economies. However, to make intelligent relationship marketing decisions, there is a need to adopt the analytic approach. This study investigates how the Analytic Hierarchy Process Model (AHP) can be used by companies in the Nigerian food and beverage industry to develop their strategic relationship marketing mix. To achieve this goal, we adopted the exploratory research method. A random sample of 67 companies was drawn out of a population of 130 companies in the Nigerian food and beverage industry based in Lagos; 600 questionnaires were administered to marketing personnel in these companies, 534 were completed, a return rate of $89 \%$. Questions for this study were generated by making use of variables identified from previous empirical studies that can be used to measure the five relationship marketing variables, namely: Trust, Relationship Commitment, Communication, Internal Marketing and Support and Cooperation. This study revealed the relative importance of the relationship marketing variables. It also showed that the trust and relationship commitment variables are significantly more important than the communication, internal marketing, and support and cooperation variables in the strategic relationship marketing mix of the companies in the Nigerian Food and Beverage Industry.
\end{abstract}

Keywords: papers, relationship marketing, strategic relationship marketing variables, Nigerian Food and Beverage Industry 


\section{Introduction}

In an era of global business and competitiveness, for organizations to survive and adapt to the dynamic and competitive marketing environment, they have to adopt different marketing strategies. However, marketing practices and strategies are situation specific and are a function of many variables: the environment, the nature of the market served, the growth stage of the organization, the types of products and services offered by the organization and the quality of organization management (Hogarth-Scoth, Watson \& Wilson, 1996; Osuagwu, 2004). In order to survive and effectively adapt to the changing environment, as well as achieve their set marketing goals and objectives, organizations will need to design different marketing strategies. Relationship marketing is one of such contemporary marketing strategies. Relationship marketing refers to the development of mutually beneficial long-term relationships and the art of creating special personal ties between an organization and its customers (Nwakanma, Jackson and Burkhalter, 2007). The relationship marketing concept lays emphasis on continuous and long-term interchange between the customers and the organization, and on the creation of more effective methods of interacting with the customers. This is because it is assumed that longer relationships may translate into repeat purchases. Repeat purchase is of interest to organizations because research has shown that it is generally more profitable to service returning customers than to attract and serve new customers (Dwyer, Schur \& Oh, 1987; Gruen, 2000; Aggarwal, Castleberry, Ridnour \& Shepherd, 2005; Tseng, 2005; Nwakanma, Jackson and Burkhalter, 2007).

In order to survive in the dynamic business environment, relationships are necessities because many products are so similar that it is only the quality of the relationships that differentiates one organization from another. Adopting relationship marketing effectively tends to give an organization competitive advantage over competitors; also, when long-term relationships exist between organizations and customers, the distance between them becomes shorter and the organization benefits from repeat purchase and the goodwill of the customer (Jackson, 1985; Groonroos, 1990; Tanner Jr., 2006; Nwakanma, Jackson and Burkhalter, 2007).

Customers are part of organizations' family; hence there is a need to ensure that they have long lasting enduring relationships with the organizations. The Nigerian marketer, like any other marketer, has to devote time to build relationships with the customers in order to gain repeat patronage (Brondmo, 2002).To do this effectively marketers have to develop an optimal strategic relationship marketing mix.

The Nigerian business environment is made up of different sectors ranging from petroleum, textiles, pharmaceuticals, to food and beverages. The business organizations in these sectors can be broadly subdivided into multinationals and indigenous organizations. Since it is not possible to study all the various sectors of the Nigerian economy, focus will be on the food and beverage sector because of its uniqueness; and also because of its strong and vibrant nature. The Nigerian food and beverage market has witnessed the influx of different types of products ranging from well-packaged standardized local beverages to international beverages. Yet companies in the Nigerian food and beverage industry may not be maximizing the business opportunities offered by the large Nigerian market. Understanding their customers' needs and satisfying them can help them compete favourably. This can be achieved through the intelligent practice of relationship marketing. To achieve these goals, there is need to use the scientific approach to examine those relationship marketing variables that can help retain customers and those that can help to facilitate future marketing activities. The Analytic Hierarchy Process (AHP) can help in this regard.

The AHP is an operational research model which can be adapted for any analysis involving pair-wise comparison. This tool was first developed by Saaty in 1980, and later improved upon in subsequent years (Saaty, 1980, 1994, 2000, and 2001). The process requires the decision maker to provide judgments about the relative importance of each criterion and then specify a preference for each decision alternative to 
each criterion. The output of the Analytic Hierarchy Process is a prioritized ranking indicating the overall preference for each of the decision alternatives (Saaty, 1980, 1994, 2000, and 2001). One advantage of the Analytic Hierarchy Process is that it is designed to handle situations in which the subjective judgments of individuals constitute an important part of the decision process. It is designed for situations in which ideas, feelings, and emotions affecting the decision process are quantified to provide a numerical scale for prioritizing the alternatives (Taha, 2006). This tool can enable the marketers in the companies in the Nigerian food and beverage industry, which is the main focus of this study, determine the relative importance of the relationship marketing variables and use this knowledge to develop their strategic relationship marketing mix.

\section{Theoretical/Conceptual Framework}

\subsection{Theoretical Framework}

Strategies are means to an end but not an end in themselves, they are the means of operationalising policies. Generally, marketing strategy has been seen as the interface between an organization and its environment (Mavondo, 2000; Dixon-Ogbechi, 2003). Corporate survival is largely driven by the people factor by relationship quality (Lundgaard, 2001). Thus, organizations need to establish and maintain enduring relationships with their customers, this can be achieved through relationship marketing. Basically, the relationship marketing concept states that organizations should maintain an enduring relationship with their customers. The purpose of relationship marketing, therefore, is to enhance marketing productivity by achieving efficiency and effectiveness, and enhancing relationships with customers and other partners, at a profit (Gronroos, 1990; Sheth \& Sisodia, 1995).

Empirical studies in relationship marketing literature revealed various relationship marketing variables such as dependence, trust, opportunism, internal marketing, satisfaction, communication, relationship commitment and support and cooperation. Those that are found to be more prominent are trust, relationship commitment, communication, internal marketing and support and cooperation (Doney \& Canon, 1997; Gabbarino \& Johnson, 1999; Simpson and Mato, 1997; Morgan \& Hunt 1994; Sirdeshmukh, Singh, \& Sabool, 2002; Yeh, 2005). Trust is the reliability of an organization's members and beliefs in their willingness to perform their duties. Relationship commitment is the psychological attachment of customers to an organization. Internal Marketing is the application of marketing techniques to the internal market i.e. employees; it is the ongoing process whereby an organization aligns, motivates and empowers employees at all functions and levels to consistently deliver a positive customer experience that helps achieve business objectives. Communication is the exchange of meaningful and timely information between firms or between firms and their customers. Support and Cooperation comprise all mutually beneficial activities embarked upon by both the organization and its customers (Lancastre \& Lages, 2004; Malewicki, 2005; Mohr, Fisher, \& Nevin, 1996; Sorce, 2002; Stershic, 2006; Yeh 2005).

Thus, relationship marketing as a strategy, leads to profitability if intelligently practiced (Groonroos, 1994a, 1994b). This study seeks to see if this is so in the Nigerian food and beverage industry and also to see if the application of analytical techniques, specifically the Analytic Hierarchy Process (AHP) can enhance the intelligent practice of relationship marketing. The Analytic Hierarchy Process is an operational research model which combines both qualitative and quantitative factors and it enables decision makers decompose the problem in a hierarchical structure (Saaty, 1980). Though there are other analytical tools such as decision theory, allocation models, simulation models just to mention but a few, that could enhance the intelligent application of relationship marketing, the AHP was chosen because it is a technique that is particularly useful in modeling complex problems, since it enables the decision maker arrange things in a hierarchical pattern.

The consumer decision making process is complex. Before consumers make decisions, they have to think and in thinking they identify objects or ideas and also the relationship among them. As they identify 
things, they have to decompose the complexity which they encounter while they synthesize the factors where they discover relationships among entities. The AHP is an important tool that is used for making decisions in situations of uncertainty where subjective judgment is quantified in a logical manner. The process requires the decision maker to provide judgments about the relative importance of each criterion and then specify a preference for each decision alternative to each criterion (Saaty, 1980; Taha, 2006).

The AHP, which is a popular decision support methodology, has been successfully applied to solve problems in different areas in the management sciences. For instance it was successfully used in accounting to create a basic Multi-Criteria Performance Management System (MCS) for a major airline as evidenced in a study conducted by Liedtka (2005), which provided evidence that AHP yields a superior model for linking strategy to shareholder wealth. In fact, in other areas in accounting literature, researchers have successfully applied the AHP to solve complex problems such as analytical review, internal control evaluation and assessment of management fraud. The AHP has also been successfully applied in many areas in marketing. For example, Timor and Tuzuner (2006) applied the AHP process in the selection of sales representatives of pharmaceutical firms; they used the AHP to determine the priorities of the factors in hiring sales representatives; Gnanasekaran et al.(2006) used AHP in supplier selection; Goh (1997) used the AHP for robot selection; Al-Harbi (2001) applied the AHP in project management; while Heeseok, Wikil, and Ingoo (1995) used the AHP model to develop a business performance evaluation system.

In a nutshell, the AHP method has been used in a wide variety of complex decision making problems such as marketing (Wind \& Saaty, 1980); finance (Hakan \& Detzler, 2002); personnel (Ramadan \& Everett, 2003), production (Chang, Wu, Lin, \& Chen, 2007); healthcare (Javalgi \& Rao, 1991; Lee \& Kwak, 1999); education (Strasser, Ozgur, \& Schroeder, 2002); and different fields of decision-making (Saaty \& Vargas, 2001). Furthermore, a survey conducted by Zahedi (1986) provided over 200 known applications of the AHP.

Given the above, the AHP is used in this study because the approach agrees well with the behaviour of decision-makers (e.g. customers) because they base their judgment on knowledge and experience and then make decisions accordingly (Al-Harbi, 2001). The diagrammatic representation of the AHP model for this study is as presented in Figure 1.

\section{Figure 1: Company Strategic Relationship Marketing Mix Hierarchy}

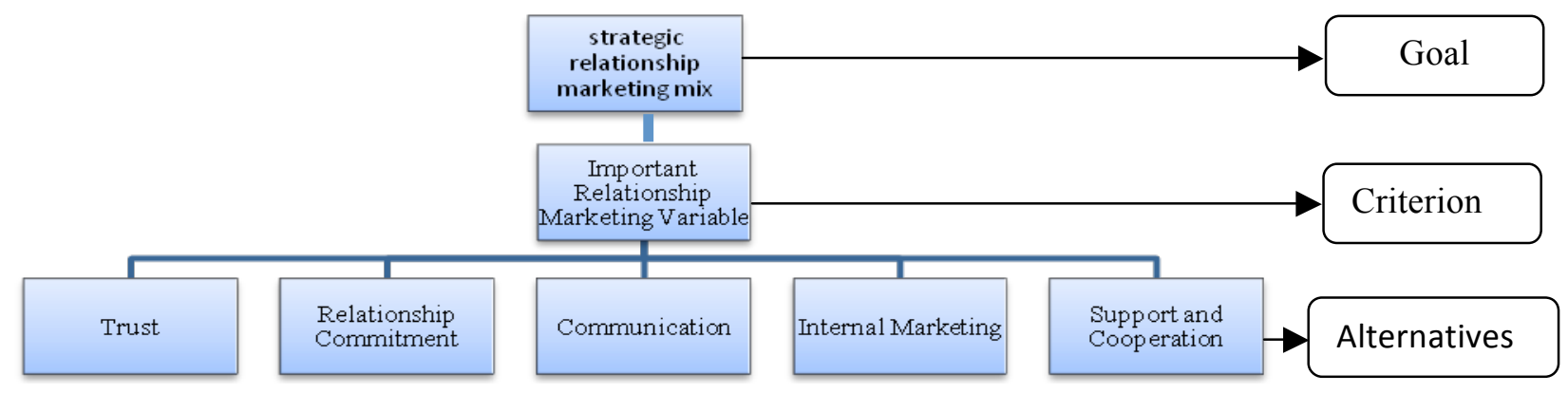

Source: Adapted from Liberatore and Nydick (2003) 
Figure 1 depicts the company strategic Relationship Marketing Mix Hierarchy which was developed using the Analytic Hierarchy Process Model. At the highest level of the hierarchy is the goal which is being pursed, in this study the goal for the company group is to determine the strategic relationship marketing mix. At the middle or intermediate level of the hierarchy is the criterion that will be used to evaluate the alternatives; in this study the criterion is the important relationship marketing variable. At the lowest level are the alternatives to be evaluated, in this study these are the five relationship marketing variables.

\subsection{Conceptual Framework}

Scholars have identified various relationship marketing variables and some of them are of the view that empirical studies in relationship marketing literature have been mainly behavioural, investigating causal relationships between certain important concepts such as dependence, trust, opportunism, commitment and satisfaction (Andaleed, 1996; Doney \& Canon, 1997; Gabbarino \& Johnson, 1999; Morgan \& Hunt 1994; Sirdeshmukh, Singh, \& Sabool, 2002) and also the effectiveness of relationship marketing activities on different behavioural loyalty measures (De Wulf, Odekerkeri-Schroder, \& Iacobucci, 2001, Verhoef, 2003). Yeh (2005) opined that relationship marketing can involve communication, trust and relationship commitment. Simpson and Mato (1997) viewed trust as the reliability of an organization's members and beliefs in their willingness to perform their duties. In addition, Mohr, Fisher, and Nevin (1996) considered relationship commitment to be the extent to which a firm's perception contributes to maintaining their cooperative relationships.

Morgan and Hunt (1994) also considered the two key concepts in relationship marketing to be trust and relationship commitment. Dwyer, Schurr and Oh (1987) defined relationship commitment as a firm's willingness to contribute to the cooperative relationship, which implies willingness to sacrifice short term benefits to achieve long-term gains; and viewed trust as the extent of the belief of one partner, in the willingness of the other partner to fulfill the contractual obligations associated with their trade relationship. Morgan and Hunt (1994) discovered that mutual trust between two firms correlates positively with relationship commitment. Kumar (1996) opined that excellent communication quality and frequent communication help improve mutual understanding, and also increase trust. Tseng (2005) proposed that relationship satisfaction, trust and relationship commitment are the core elements of relationship quality. Given this, the following conceptual model is developed for this study.

Figure 2: $\quad$ Conceptual Model of Relational Interaction in The Nigerian Food and Beverage Industry

Relationship Marketing and the Analytic Hierarchy Process

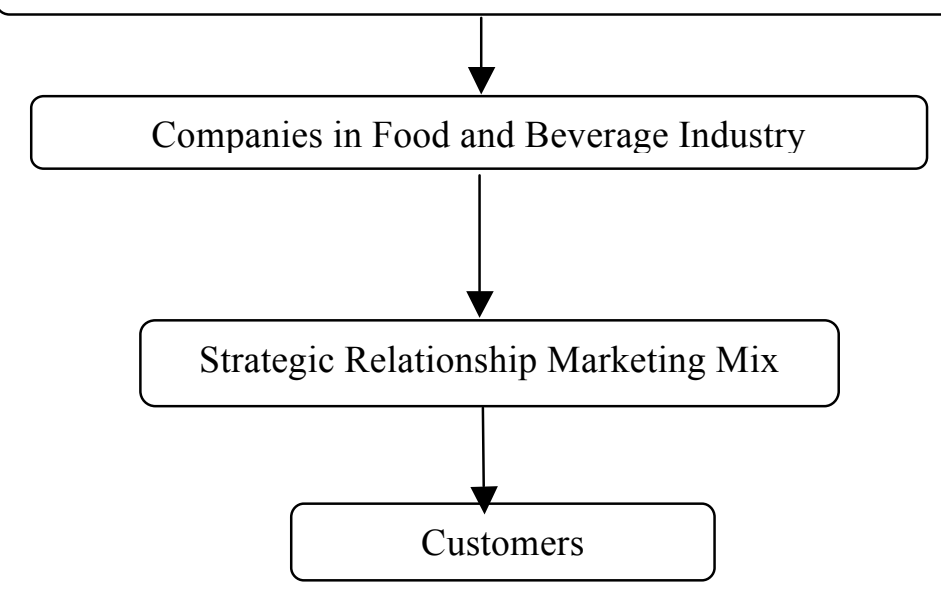


Figure 2 depicts a model of the relational interaction and how this portion of the study fits into the overall process proposed. Basically this is to see how relationship marketing and the analytic hierarchy process can be used by indigenous and multinational companies in the Nigerian food and beverage industry to develop their strategic relationship marketing mix. This strategic relationship marketing mix will be directed to customers and it will affect customer patronage. (Note: the customers' perceptions of the alternatives are also addressed and comparisons between their choices and the companies' choices are compared in a separate study.)

\section{Methodology}

\subsection{Objectives of study}

This study aims to investigate how the Analytic Hierarchy Process Model (AHP) can be used by companies in the Nigerian Food and Beverage industry to develop their strategic relationship marketing mix. To this effect, it sought to:

1. investigate the proportion of companies in the Nigerian food and beverage industry that are familiar with, and that adopt, the Analytic Hierarchy Process in making relationship marketing decisions.

2. determine the relative importance of the relationship marketing variables in the strategic relationship marketing mix of companies in the Nigerian food and beverage industry using the Analytical Hierarchy Process model.

\subsection{Research hypothesis}

i. $\quad \mathbf{H}_{1}$ : The relationship marketing variables such as trust and relationship commitment are more important than communication, internal marketing, and support and cooperation in the strategic relationship marketing mix of indigenous companies in the Nigerian food and beverage industry.

ii. $\quad \mathbf{H}_{2}$ : The relationship marketing variables such as trust and relationship commitment are more important than communication, internal marketing, and support and cooperation in the strategic relationship marketing mix of multinational companies in the Nigerian food and beverage industry.

iii. $\quad \mathbf{H}_{3}$ : There is a high correlation between the relative importance ranking attached to the strategic relationship marketing mix variables of indigenous companies and multinationals.

\subsection{Research design}

This study was conducted using the exploratory research design. The research approach used is a combination of both the quantitative and the qualitative research methods as suggested by Zebal (2003). The population of this study is made up of all indigenous companies and multinationals in the Nigerian food and beverage industry based in Lagos. The multinationals and indigenous companies studied are those that produce food and beverage as listed by the Nigerian Business Directory (2007) and by the National Agency for Food and Drug Administration and Control - NAFDAC (2007).

\subsection{Sampling Procedure and Instrument}

A sample of 67 companies was drawn out of a population of 130 companies in the Nigerian food and beverage industry based in Lagos using the multistage sampling technique. Simple random sampling technique was used to select the companies; the judgmental sampling technique was used to select the category of employees to study in the selected companies, while the disproportionate stratified sampling technique was used to select the individual employees sampled in the units. Questions for this study were generated by making use of variables identified from previous empirical studies that can be used to measure the five relationship marketing variables found to be most prominent in literature, namely: Trust, Relationship Commitment, Communication, Internal Marketing and Support and Cooperation. The 
instrument was pilot tested twice, once with marketing experts and then retested on 60 respondents consisting of employees of the companies in the food and beverage industry in Lagos metropolis. The instruments were validated through the pilot studies by using experts and a sample of respondents for content validity (Hahn et al. 2000). Overall 600 questionnaires were administered, and 534 were completed, with a return rate of $89 \%$; however during data editing it was discovered that with regards to the relative importance scaled part of the questionnaire, 466 of the instruments were correctly filled representing $77.7 \%$.

\subsection{Data Collection Methods}

A two-phase data collection approach, which includes both a qualitative phase and a quantitative phase, was adopted. The qualitative data collection phase entailed collecting data in form of words based on documents obtained from secondary sources of information such as journals, textbooks and the internet; and also through the open-ended questions in the research instruments. In gathering quantitative data, the questionnaire was used; and to expedite their quick return, they were administered manually and collected at a mutually agreed time from the respondents.

\subsection{Identification and Measurement of Variables}

From literature search the following dependent and independent variables are identified:

Dependent Variables: Strategic Relationship Marketing Mix (SRMX) Independent Variables: Relationship marketing variables such as: - Trust (T), Relationship Commitment (RC), Communication (C), Internal Marketing (IM), and Support and Cooperation (SC).

Therefore, we posit that: Strategic Relationship Marketing Mix of food and beverage companies is a function of the relative importance ranking of Trust, Relationship Commitment, Communication, Internal Marketing, and Support and Cooperation. That is: $\mathrm{SRMX}=f(\mathrm{~T}, \mathrm{RC}, \mathrm{C}, \mathrm{IM}, \mathrm{SC})$.

Strategic Relationship Marketing Mix (SRMX): Two 9-points relative importance scaled questions were used to measure the relative importance of the relationship marketing variables in the strategic relationship marketing mix for both multinationals and indigenous companies. The Expert Choice (EC8) software was used to analyse the data.

Familiarity with the Analytic Hierarchy Process (FAHP): This was measured using three major items. Two of the items were developed using closed-ended and one with an open-ended question. The information sought include: whether respondents are aware of the Analytic Hierarchy Process, usage of Analytic Hierarchy Process in making marketing decisions and period since when the Analytic Hierarchy Process has been adopted. The Cronbach's $\alpha$ reliability score was generated for the indigenous companies and multinationals group. A Cronbach's $\alpha$ reliability score of .720 was generated for indigenous companies group scale and a Cronbach's $\alpha$ reliability score of .912 was generated for multinationals group scale. These suggest very good internal reliability.

\subsection{Administration Methodology}

Five research assistants were employed to administer the instruments. They include two recent male post graduates, two recent male graduates and one female undergraduate student. These research assistants were given two days training by the researcher. The instruments were administered over a period of five months. 


\section{RESULTS}

\subsection{Demographic description - Indigenous Companies}

The descriptive analysis showed the respondents from these companies to be young, $87.6 \%$ less than 40 years old; with $72.2 \%$ with less than five years working experience; and $71 \%$ with less than five years experience in a marketing department. Fifty eight percent (57.9\%) had a B.Sc. or equivalent, $47 \%$ reported they were in middle management, $37.2 \%$ in lower management, and $14.7 \%$ in top level management. The breakdown of gender ( $45.9 \%$ female, $54.1 \%$ male) and marital status $(46.2 \%$ single, $43.6 \%$ married) was fairly equal; religion showed a Muslim predominance, $48.9 \%$ over, Christian 39.5\%.

\subsection{Demographic description - Multinationals}

The descriptive analysis showed the respondents from these companies to be young, $88.4 \%$ less than 40 years old; with $64.1 \%$ with less than five years working experience; and $79 \%$ with less than five years experience in a marketing department. Seventy seven percent $(76.9 \%)$ had a B.Sc. or equivalent, $56.3 \%$ reported they were in middle management, $31.7 \%$ in lower management, and $3.4 \%$ in top level management. The breakdown of gender ( $46.3 \%$ male, $50.7 \%$ female) and marital status (43.7\% single, $53.3 \%$ married) was almost fairly equal; religion showed a Christian predominance, $82.1 \%$ over, Muslim $14.9 \%$.

\subsection{Demographic description - Combined}

The descriptive analysis showed the respondents from the companies to be young, $88 \%$ less than 40 years old; with $68.2 \%$ with less than five years working experience; and $75 \%$ with less than five years experience in a marketing department. Sixty seven percent $(67.4 \%)$ had a B.Sc. or equivalent, $51.7 \%$ reported they were in middle management, $34.45 \%$ in lower management, and $09 \%$ in top level management. The breakdown of gender ( $48.3 \%$ female, $50.2 \%$ male) and marital status $(44.9 \%$ single, $48.5 \%$ married) was fairly equal; religion showed a Christian predominance, $60.8 \%$ over, Muslim 31.9\%.

\subsection{Results of familiarity with Analytic Hierarchy Process}

Findings revealed that with regards to in the indigenous companies, most of the respondents $(63.6 \%)$ are not aware of the Analytic Hierarchy process. However, most of the few respondents (36.5\%) that are aware of the Analytic Hierarchy process use it in making marketing decisions. Also, most of the respondents $(75.56 \%)$ did not state since when their organizations have been adopting the AHP; out of the few that did, the majority (24.59\%) stated that their organizations have been adopting it since inception.

However, with regards to the multinational companies, slightly above half of the respondents (52.5.3\%), stated that they are aware of the Analytic Hierarchy Process (AHP) and most of them use it for making marketing decisions. Also, content analysis of the open-ended questions revealed that most of the respondents (76.12\%) did not state since when their organizations have been adopting the AHP; out of the few who indicated this, most of them (42.19\%) stated that their organizations have been adopting it since inception. Overall, it can be said that most of the companies in the Nigerian food and beverage industry are not aware of the Analytic Hierarchy Process; however most of the few that are aware of it use it in making marketing decisions.

\subsection{The AHP Consistency Ratios (CR)}

The results showed that the consistency ratios (CR) of all the AHP analyzed data for the two groups (indigenous and multinational companies) were all acceptable because they did not exceed 0.10 . 


\subsection{Results on Relative Importance of Relationship Marketing Variables -AHP Model}

Tables 1, 2, 3, 4 and 5 below present the results of the respondents' pair-wise comparison of the relationship variable concepts such as: trust, relationship commitment, communications, internal marketing and support and cooperation. The results in order of relative importance yield the following: trust, relationship commitment, communications, internal marketing and support and cooperation.

Table 1. Frequency of Indigenous companies' relative importance ranking of relationship marketing variables.

\begin{tabular}{lllllll}
\hline Variables & Level 1 & Level 2 & Level 3 & Level 4 & Level 5 & Total \\
\hline Trust & $\mathbf{1 7 7}$ & 50 & 9 & 2 & 0 & 238 \\
Relationship Commitment & 61 & $\mathbf{1 2 8}$ & 43 & 5 & 1 & 238 \\
Communication & 6 & 45 & $\mathbf{1 3 5}$ & 46 & 6 & 238 \\
Internal Marketing & 1 & 9 & 40 & $\mathbf{1 2 4}$ & 64 & 238 \\
Support and Cooperation & 0 & 0 & 9 & 61 & $\mathbf{1 6 8}$ & 238 \\
\hline
\end{tabular}

Table 2. Frequency of Multinational companies' relative importance ranking of relationship marketing variables.

\begin{tabular}{lllllll}
\hline Variables & Level 1 & Level 2 & Level 3 & Level 4 & Level 5 & Total \\
\hline Trust & $\mathbf{1 6 3}$ & 53 & 11 & 1 & 0 & 228 \\
Relationship Commitment & 60 & $\mathbf{1 2 3}$ & 44 & 1 & 0 & 228 \\
Communication & 8 & 46 & $\mathbf{1 2 3}$ & 48 & 3 & 228 \\
Internal Marketing & 1 & 5 & 36 & $\mathbf{1 4 1}$ & 45 & 228 \\
Support and Cooperation & 0 & 0 & 7 & 43 & $\mathbf{1 7 8}$ & 228 \\
\hline
\end{tabular}

Table 3. Frequency of combined companies' relative importance ranking of relationship marketing variables.

\begin{tabular}{lcccccc}
\hline \hline Variables & Level 1 & Level 2 & Level 3 & Level 4 & Level 5 & Total \\
\hline Trust & $\mathbf{3 4 0}$ & 103 & 20 & 3 & 0 & 466 \\
Relationship Commitment & 121 & $\mathbf{2 5 1}$ & 87 & 6 & 1 & 466 \\
Communication & 14 & 91 & $\mathbf{2 5 8}$ & 94 & 9 & 466 \\
Internal Marketing & 2 & 14 & 76 & $\mathbf{2 6 5}$ & 109 & 466 \\
Support and Cooperation & 0 & 0 & 16 & 104 & $\mathbf{3 4 6}$ & 466 \\
\hline
\end{tabular}

Table 4. Indigenous Companies' Means

\begin{tabular}{llc}
\hline \hline Variables & Mean & 95\% Confidence Interval \\
\hline Trust & .4309 & .4175 to .4442 \\
Relationship Commitment & .2815 & .2678 to .2952 \\
Communication & .1558 & .1472 to 1643 \\
Internal Marketing & .0830 & .0768 to .0892 \\
Support and Cooperation & .0488 & .0457 to .0520 \\
\hline
\end{tabular}


Table 5. Multinational Companies Means

\begin{tabular}{llc}
\hline \hline Variables & Mean & 95\% Confidence Interval \\
\hline Trust & .4148 & .3986 to .4311 \\
Relationship Commitment & .2793 & .2653 to .2933 \\
Communication & .1664 & .1568 to .1759 \\
Internal Marketing & .0861 & .0797 to .0924 \\
Support and Cooperation & .0534 & .0493 to .0575
\end{tabular}

\subsection{Results on Hypothesis Testing}

The variable trust is clearly regarded as the priority when compared against any of the other variables, by the majority of the respondents. Relationship commitment is of secondary importance followed by communication, internal marketing and support and cooperation. The above mentioned ordered list is very consistent among respondents, as shown in Tables 1 and 2. For the indigenous group, (Table 1) trust is chosen first by $74 \%$ of the respondents, relationship commitment second by $54 \%$ of the respondents, communication third by $57 \%$, internal marketing fourth by $52 \%$ and support and cooperation fifth by $71 \%$. The highest number of respondents off diagonal by two categories or more is eighteen. For the multinational companies' respondents, (Table 2) trust was chosen first by $71 \%$, relationship commitment by $54 \%$, communication third by $54 \%$, internal marketing fourth by $62 \%$ and support and communication fifth by $78 \%$. The highest number of respondents off diagonal by two categories or more is eighteen for this group as well.

Tables 4 and 5 present the means and the $95 \%$ confidence intervals. It is clear that trust and relationship commitment account for the majority of weights, over two thirds. Trust alone accounts for more weight than the lower three in combination, for both indigenous and multinationals.

$\mathrm{H}_{1}$ and $\mathrm{H}_{2}$ are supported in that the results of the AHP analysis for both the indigenous companies and the multinationals showed trust and relationship commitment to be more important than the variables of communication, internal marketing and support and cooperation. This finding was consistent throughout the AHP analysis. The perfectly correlated rank order of the variables in each group supports $\mathrm{H}_{3}$. If the raw weights are used in the correlation, the correlation value is almost perfect; there is no question that $\mathrm{H}_{3}$ is also supported.

\subsection{Discussion}

The results of the AHP analysis are clear and consistent. The marketing personnel of both the indigenous and the multinational companies rank and weight the relationship marketing variables in the order hypothesized: trust, relationship commitment, communication, internal marketing and support and communication, with trust the most important by far. These results were true for both groups despite their noted demographic differences in education and religion. The confidence intervals around the means of each variable for each respondent group, shown in Tables 4 and 5, overlap again reflecting the consistency of view point. If one really searches for a difference between the groups it might be said that the weights for communication and support and cooperation for the indigenous groups are slightly lower than even the lower confidence bound in each of these categories for the multinationals, thus indigenous marketers might be giving these variables "slightly" less value. 
This consistency and clarity of outcomes is in contrast to one analysis performed on the data from the Likert scale part of this questionnaire, part a, as part of another study. In paired t tests of the difference between a scale comprised of trust and relationship commitment items and one of the communication, internal marketing and support and communication sets of items, done for each set of respondents, results showed the two scales to be significantly different $(\mathrm{p}<.001)$ for the multinational group with an average mean difference of .22044, from 4.3691 to 4.148. There was no significant difference $(\mathrm{p}<.14)$ for the indigenous group on these two scales, means of 4.3865 and 4.3591 , respectively. These means, and in most of the analyses of the Likert scale, the ratings were relatively high or positive and that clearly presents a problem if the objective is not simply to determine favorability, but also to determine relative importance.

\subsection{Conclusion and Implications}

As seen in the comparison between approaches referred to in the above discussions, AHP is invaluable in that it provides a way for the decision maker to ascertain not just the opinions of the respondents on certain facets of, in this case, relationship marketing variables, but to be able to determine the respondents priorities in determining the marketing mix. They are clear and concise and lead to the conclusion that the importance of the variables of trust, relationship commitment, communication, internal marketing and support and cooperation, in that order, are the same for indigenous and multinational companies operating in the Nigerian food and beverage industry.

Beyond the determining of relative priorities the AHP process yields weightings that have been given to the marketing relationship variables. These can lead to a wealth of information. Comparisons among company groups and even between company groups and customers could provide useful and interesting data. It would be interesting to compare these weightings with the actual operations of the business. Do companies actually allocate their marketing dollars to their mix in this ratio? Do they factor in the customer weights based on the AHP process? How do marketing strategies based on this type of analysis compare with "best practices?" These questions could provide the basis for future research endeavors. 


\section{REFERENCES}

Aggarwal, P., Castleberry, S.B., Ridnour, R., \& Shepherd, C.D. (2005). "Salesperson Empathy and Listening: Impact on Relationship Outcomes". Journal of Marketing Theory and Practice, Statesboro, Summer, 13 (3), 16-31.

Andaleed, S. S. (1996). “An Experimental Investigation Of Satisfaction And Commitment In Marketing Channels: The Role Of Trust And Dependence". Journal of Retailing, 72(1), 77-93.

Brondmo (2002), in Forrester Research (2002). "Marketing Tools For The $21^{\text {st }}$ Century". Semaphore Inc.

Chang, C., Wu, C., Lin, C., \& Chen, H. (2007). “Application Of AHP And Sensitivity Analysis For Selecting The Best Slicing Machine". Computer and Industrial Engineering, March, 53(2), 296-307.

De Wulf, K., Odekerken-Schroder, G., \& Iacobucci, D. (2001). "Investments in Consumer Relationships: A Cross-Country and Cross-Industry Exploration”. Journal of Marketing, 65(4), 33-50.

Dixon-Ogbechi, Bolajoko N. (2003). The Fundamentals of Business Policy and Strategy. Lagos: Philglad Nigeria Limited.

Doney, P. M. \& Cannon, J. P., (1997). "An Examination of the Nature of Trust in Buyer-Seller Relationships". Journal of Marketing, April, 61, 35-51.

Dwyer, F.R.; Schurr, P., \& Oh, S., (1987). "Developing Buyer-Seller Relationships". Journal of Marketing, April, 51, 11-27.

Garbarino, E., \& Johnson, M. S., (1999). "The Different Roles of Satisfaction, Trust, and Commitment in Customer Relationships". Journal of Marketing, April, 63, 70-87.

Gnanasekaran, S., Selladurai, V., \& Manimaran, P. (2006). "Application of Analytical Hierarchy Process in Supplier Selection: An Automobile Industry Case Study". South Asian Journal of Management, Oct-Dec.

Goh C. (1997). “Analytic Hierarchy Process for Robot Selection”. Journal of Manufacturing Systems, 16 (5), 381-6.

Grönroos, C. (1990). "Relationship Approach to Marketing In Service Contexts: The Marketing and Organizational Behavior Interface”. Journal of Business Research, January, 20 (1), 3-11.

Groonroos, C. (1994a). "From Marketing Mix to Relationship Marketing: Towards a Paradigm Shift in Marketing". Management Decision, 32(2), 4-20.

Groonroos, C. (1994b). "Quo Vadis Marketing? Towards a Paradigm Shift in Marketing”. Journal of Marketing Management, 18, 347-360.

Gruen, T. W. (2000). "Relationship Marketing Activities, Commitment, and Membership Behaviours in Professional Associations”. Journal of Marketing, 64(3), 34-50. 
Hahn, Ellen J.; Hall, Lynne A.; Rayens, Mary Kay; Burt, April V.; Corley, Donna \& Sheffel, Kristy Lea (2000). "Kindergarten Children's Knowledge And Perceptions Of Alcohol, Tobacco, And Other Drugs". Journal of School Health, February, 70 (2):51-55.

Hakan, Saraoglu \& Detzler, Miranda Lam (2002). “A Sensible Mutual Fund Selection Model”, Financial Analysts Journal, May/June, 58(3), 60-72.

Heeseok, L., Wikil, K., \& Ingoo, H. (1995). "Developing a Business Performance Evaluation System: An Analytical Hierarchical Model”. The Engineering Economist, Summer.

Hogarth-Scoth, S., Watson, K., \& Wilson, N. (1996). "Do Small Business Have To Practice Marketing To Survive And Grow?”. Marketing Intelligence And Planning, 14(1), 6-18.

Jackson, B.B. (1985). Winning and Keeping Industrial Customers: The Dynamics of Customer Relationships. Lexington, MA: D.C. Heath and Company.

Javalgi, R., Rao, S. R., \& Thomas, E. (1991). "Choosing a Hospital: Analysis of Consumer Tradeoffs". Journal of Health Care Marketing, 11(1), 12-23.

Kumar, N. (1996). "The power of Trust in Manufacture-Retailer Relationships". Harvard Business Review, 74(6), 92-106.

Lancaster, A., \& Lages, L. (2004). "The Relationship between Buyer and a B2B e-Marketplace: Cooperation Determinants in an Electronic Market Context". FEUNL Working Paper No. 443.

Lee, C., \& Kwak, N. K. (1999). "Information Resource Planning for a Health-Care System using an AHP- Based Goal Programming Method". The Journal of Operational Research Society, 50(12), 11911198.

Liberatore, M. J., \& Nydick, R.L. (2003). Decision Technology: Modelling, Software and Applications. Hoboken, NJ: John Wiley \& Sons, Inc.

Liedtka, S. L. (2005). "Analytic hierarchy process and multi-criteria performance management systems". Cost Management, (November/December), 30-38.

Lundgaard, W. (2001)."Contemporary Issues for Organizational Survival". Ingenta connect knowledge: the key to organizational survival.www.ingentaconnect.com/content/mcb/100/2001/00000013/

00000003/art-00002.

Malewicki, S. D. (2005). "Member Involvement in Entrepreneur Network Organizations: The Role of Commitment and Trust". Journal of Developmental Entrepreneurship, Norfolk, August, 10(2), 141-165.

Mavondo, F.T. (2000). "Marketing As A Form Of Adaptation: Empirical Evidence From A Developing Economy”. Marketing Intelligence And Planning, 18(5), 256-272.

Mohr, J. J., Fisher, R. J., \& Nevin, J. R. (1996). "Collaborative Communication in Interfirm Relationships: Moderating Effects of Integration and Control". Journal of Marketing, 60(1), 103-15.

Morgan, R. M., \& Hunt, S. D. (1994). "The Commitment-Trust Theory of Relationship Marketing”. Journal of Marketing, 58, 20-38. 
NAFDAC (2007). "Sheets A, B,C of the list of Food and Beverage Manufacturing Companies in Nigeria". Files in the Department of Public Relations, The National Agency for Food and Drug Administration And Control Central Laboratory, Oshodi, unpublished paper.

Nigeria Business Directory (2007). "Nigeria Business Directory and Yellow Pages". http://www.nigeriagalleria.com/Manufacturing_and_Production/Food_and_Beverages.html, retrieved $17^{\text {th }}$, June.

Nwakanma, H., Jackson, A.S., \& Burkhalter, J.N. (2007). Relationship Marketing: An Important Tool For Success In The Marketplace. Journal of Business \& Economics Research, February, 5 (2), 55-64.

Osuagwu, Linus (2004). "Relationship Marketing Strategies In Nigerian Companies". unpublished paper.

Ramadan, H., \& Everett, S. (2003). "Employee Performance Evaluation Using The Analytic Hierarchy Process". Academy of Information and Management Sciences Journal, 6(2), 67-76.

Saaty, T.L. (1980). The Analytical Hierarchy Process. New York: McGraw-Hill.

Saaty, T. L. (1994). "How to Make a Decision: The Analytic Hierarchy Process". Interfaces, 24, 19-43.

Saaty, T.L. (2000). Fundamentals of Decision Making And Priority Theory With Analytical Hierarchy Process. Pittsburgh, PA: RWS Publications.

Saaty, Thomas L. (2001). Decision Making For Leaders, $3^{\text {rd }}$ ed., Pittsburgh, PA: RWS Publications.

Saaty, T. L. \& Vargas, L. (2001). Models, Methods, Concepts \& Applications of the Analytic Hierarchy Process. Kluwer Academic Publishers.

Sheth, J. N., \& Sisodia, R. (1995). Improving the Marketing Productivity, in Encyclopedia of Marketing for the Year 2000, Chicago American Marketing Association - NTC.

Simpson, J. T., \& Mato, D. T. (1997). "Relationship Management: A Call for Fewer Influence Attempts?"..Journal of Business Research, 39(7), 209-18.

Sirdeshmukh, D., Singh, J., \& Sabol, B. (2002)."Consumer Trust, Value, and Loyalty in Relational Exchanges". Journal of Marketing, 66(1), 15-37.

Sorce, P. (2002). Relationship Marketing Strategy. Rochester, NY: A Research Monograph of the Printing Industry Center at RIT, September,No. PICRM-2002 04.

Stershic, S.F. (2006). "Internal Marketing Best Practice Study". Quality Service Marketing, September, 26, www.qualityservicemarketing.blogs.com.

Strasser, S.E., Ozgur, C., \& Schroeder, D.L. (2002). "Selecting a Business College Major: An Analysis of Criteria and Choice using the Analytical Hierarchy Process". Mid-American Journal of Business, Fall , 17(2), 47-56.

Taha, H.A. (2006). Operations Research: An Introduction. $8^{\text {th }}$ ed., New Delhi: Prentice-Hall of India Private Limited. 
Tanner J.F. Jr., in Olasz, S.C. (2006). "Marketing's Role in a Relationship Age", Baylor Business Review, WACO, Spring, 24(2), 2-7.

Timor, M., \& Tuzuner, L. (2006). "Sales Representative Selection of Pharmaceutical Firms by Analytical Hierarchy Process". Journal Of American Academy of Business, Cambridge, March, 8(1), 287-293.

Tseng, Y. (2005). "How Can Marketing Tactics Build Behavioural Loyalty?". The Business Review, Cambridge Hollywood, summer, 3(2), 298-302.

Verhoef, P.C. (2003). "Understanding the Effect of Customer Relationship Management Efforts on Customer Retention and Customer Share Development". Journal of Marketing, October, 67, $30-45$.

Wind, Y., \& Saaty, T.L. (1980). "Marketing Applications of the Analytic Hierarchy Process". Management Science, July, 26(7), 641-658.

Yeh, Y. (2005). "Identification of Factors Affecting Continuity of Cooperative Electronic Supply Chain Relationships: Empirical Case of The Taiwanese Motor Industry". Supply Chain Management, Bradford, 10(3/4).

Zahedi, F. (1986). "The Analytical Hierarchy Process: A Survey of the Method and its Applications", Interfaces, 16, 96-108.

Zebal, M.A. (2003). "A Synthesis Model of Market Orientation For A Developing Country The Case of Bangladesh". Ph.D Thesis Presented to Department of Hospitality, Tourism and Marketing, Faculty of Business and Law. 